\title{
Impact of IFRS Convergence in India: An Evidence from First-Time Adoption of Indian Accounting Standards
}

\author{
T.P.Ghosh ${ }^{1}$ \\ ${ }^{1}$ Institute of Management Technology, Dubai, United Arab Emirates \\ Correspondence: T.P.Ghosh, Institute of Management Technology, International Academic City, Dubai, United Arab \\ Emirates. E-mail: tpghosh@imt.ac.ae
}

Received: January 9, 2019

Accepted: January 28, 2019

Online Published: February 1, 2019

doi:10.5430/afr.v8n1p157

URL: https://doi.org/10.5430/afr.v8n1p157

\begin{abstract}
Based on first set of Ind AS compliant financial statements released by Indian companies in Phase I of the IFRS convergence process, this study aims at examining whether profit and equity are significantly impacted because of IFRS convergence, and whether such impact is size dependent. Research hypotheses are designed to re-verify a well established 'value relevance' theorem of IFRS adoption / convergence in the Indian context and to evaluate if net worth based phasing of IFRS implementation in India as well as exemption from IFRS adoption is justified.

Paired samples t-test and Wilcoxon Signed Ranked test are applied to a sample of 100 Ind AS compliant listed companies for comparing means of IGAAP equity and Ind AS equity on the date of transition, i.e. 1 April 2015, and on the comparative period reporting date, i.e. 31 March 2016. Ind AS total comprehensive income is compared to IGAAP profit for the comparative period i.e. 2015-16.

Results show that Ind AS adjustments to equity have significant impact despite IFRS carve outs in India but total comprehensive income as per Ind AS is not significantly different from IGAAP profit although various items of other comprehensive income (OCI) are recognised in the IFRS convergence process. This implies that influence of OCI on profit of the non-financial sector companies in India is not significant. Also, applying multiple regression analysis it is found that size of the company is relevant in explaining change in equity caused by IFRS convergence.
\end{abstract}

Keywords: amortised cost, fair value through profit and loss, other comprehensive income, IFRS convergence, Indian accounting standards

\section{IFRS Convergence in India}

Significant foreign stock holding in Indian companies and wide participation of foreign institutional investors in Indian securities market necessitate adoption of uniform financial reporting system in consonance to G20 commitments. Also, improvement in International Financial Reporting Standards (IFRS) during the last decades prompted India to set IFRS convergence agenda as early in 2011-12 which was delayed till 2016-17 to facilitate smooth transition by Indian companies. Since the gap between accounting standards (IGAAP) ${ }^{1}$ which are based on pre-2004 version of International Accounting Standards and the IFRS has widened over the years, IFRS convergence has been viewed as a major qualitative change in the Indian financial reporting system.

India has opted for phased implementation of Indian Accounting Standards (Ind AS) ${ }^{2}$, the converged IFRS, as a replacement of the IGAAP prioritized by the size of net worth possibly for balanced utilization of IFRS professionals. Unlisted companies having net worth of less than Rs. 2.5 billion are exempted from application of converged IFRS. Ind ASs are significantly different from IGAAP as regards measurement, recognition and disclosure principles of various financial statement elements. Twenty-two major differences that could significantly impact IGAAP based financial statement elements in the IFRS convergence process are presented in Appendix II.

Ind ASs are based on partial fair value measurement (hybrid measurement model followed in the IFRSs) by which financial assets are primarily measured at fair value while cost alternatives are allowed for tangible fixed assets and intangibles, IGAAP are primarily based on cost model. Moreover, application of the revaluation model to intangible assets is constrained to observable market price in the line of IAS 38 Intangible Assets, and investment property is further constrained to be measured at historical cost because of fair value carve out in Ind AS 40 Investment Property. Applicability of fair value measurement principle of IFRS is also constrained by amortized cost measurement basis to financial assets and financial liabilities which have scheduled cash flows representing solely principal and interest. 
In a way the amortized cost, which is measured as the present value of future cash flows discounted at effective interest rate or market yield on the date of transaction, is secluded from the volatility of market price. A major portion of the financial assets and financial liabilities would usually fall in this category which further restricts the scope of fair value measurement. Comparative measurement bases of Ind AS and IFRS are presented in Table 1.

Table 1. Comparative measurement Bases of Ind AS/ IFRS and IGAAP

\begin{tabular}{|c|c|c|c|c|}
\hline \multirow[t]{2}{*}{ Type of Assets } & \multicolumn{2}{|c|}{ Ind AS } & \multicolumn{2}{|l|}{ IGAAP } \\
\hline & $\begin{array}{l}\text { Initial } \\
\text { recognition }\end{array}$ & $\begin{array}{l}\text { Subsequent } \\
\text { measurement }\end{array}$ & $\begin{array}{l}\text { Initial } \\
\text { recognition }\end{array}$ & $\begin{array}{l}\text { Subsequent } \\
\text { measurement }\end{array}$ \\
\hline $\begin{array}{l}\text { Property, Plant and } \\
\text { equipment } \\
\text { Bearer Plant }\end{array}$ & Cost & $\begin{array}{l}\text { Cost or revaluation } \\
\text { model }\end{array}$ & Cost & Cost \\
\hline Intangible assets & Cost & $\begin{array}{l}\text { Cost or revaluation } \\
\text { model }\end{array}$ & Cost & Cost \\
\hline Investment property & Cost & Cost & Cost & Cost \\
\hline $\begin{array}{l}\text { Biological assets } \\
\text { Except Bearer Plant }\end{array}$ & $\begin{array}{l}\text { Fair value less } \\
\text { costs to sell }\end{array}$ & $\begin{array}{l}\text { Fair value less } \\
\text { costs to sell }\end{array}$ & Cost & Cost \\
\hline Inventories & $\begin{array}{l}\text { Lower of cost } \\
\text { and net } \\
\text { releasable value }\end{array}$ & $\begin{array}{l}\text { Lower of cost and } \\
\text { net releasable value }\end{array}$ & $\begin{array}{l}\text { Lower of cost } \\
\text { and net } \\
\text { releasable value }\end{array}$ & $\begin{array}{l}\text { Lower of cost and } \\
\text { net releasable } \\
\text { value }\end{array}$ \\
\hline Long term investments & Fair value & $\begin{array}{l}\text { Amortized cost or } \\
\text { fair value }\end{array}$ & Cost & $\begin{array}{l}\text { Cost unless there } \\
\text { is permanent } \\
\text { diminution in cost }\end{array}$ \\
\hline Short term investments & Fair value & Fair value & Cost & $\begin{array}{l}\text { Lower of cost or } \\
\text { market value }\end{array}$ \\
\hline Stand-alone derivatives & Fair value & Fair value & Cost & Cost \\
\hline Financial Liabilities & Fair value & $\begin{array}{l}\text { Amortized cost or } \\
\text { fair value }\end{array}$ & Maturity value & Maturity value \\
\hline Provisions & Present value & $\begin{array}{l}\text { At present value or } \\
\text { fair value }\end{array}$ & Maturity value & Maturity value \\
\hline $\begin{array}{l}\text { Assets acquired in } \\
\text { business combination }\end{array}$ & Fair value & $\begin{array}{l}\text { Cost or revaluation } \\
\text { model }\end{array}$ & $\begin{array}{l}\text { Purchase method } \\
\text { Fair value }\end{array}$ & Cost \\
\hline $\begin{array}{l}\text { Liabilities acquired in } \\
\text { business combination }\end{array}$ & Fair value & $\begin{array}{l}\text { Amortized cost or } \\
\text { fair value }\end{array}$ & Fair value & Cost \\
\hline $\begin{array}{l}\text { Assets acquired in } \\
\text { business combination }\end{array}$ & & & $\begin{array}{l}\text { Pooling of } \\
\text { Interest method } \\
\text { At carrying } \\
\text { amount of the } \\
\text { acquire }\end{array}$ & $\begin{array}{ll}\text { At } & \text { carrying } \\
\text { amount } & \text { of the } \\
\text { acquire } & \end{array}$ \\
\hline $\begin{array}{l}\text { Liabilities acquired in } \\
\text { business combination }\end{array}$ & & & $\begin{array}{l}\text { At carrying } \\
\text { amount of the } \\
\text { acquire }\end{array}$ & $\begin{array}{l}\text { At } \\
\text { amount of the } \\
\text { acquire }\end{array}$ \\
\hline $\begin{array}{l}\text { Investments in } \\
\text { subsidiary, associate and } \\
\text { joint ventures in separate } \\
\text { financial statements }\end{array}$ & $\begin{array}{l}\text { Cost or fair } \\
\text { value }\end{array}$ & Cost or fair value & Cost & Cost \\
\hline $\begin{array}{l}\text { Non-current Assets held } \\
\text { for sale }\end{array}$ & $\begin{array}{l}\text { Lower of cost } \\
\text { and fair value } \\
\text { less cost to sale }\end{array}$ & $\begin{array}{l}\text { Lower of cost and } \\
\text { fair value less cost } \\
\text { to sale }\end{array}$ & Cost & Cost \\
\hline
\end{tabular}


Despite limited application of fair value, and use of lesser percentage of financial assets by non-financial sector companies, it is expected that differences in recognition and measurement principles of IGAAP and Ind AS should cause significant impact. Further, total comprehensive income (TCI) as a new profit measure includes profit after tax (PAT) and various items of other comprehensive income (OCI) in accordance with IAS 1/ Ind AS 1 Presentation of Financial Statements which would cause difference between IGAAP and Ind AS profit. Therefore, it is considered important to enquire if IFRS convergence in India produces significantly different equity and profit numbers. In the context of phased implementation of Ind AS based on size of net worth, it is considered relevant to further enquire if difference in equity is size dependent. These research queries would help to substantiate value relevance studies using IFRS based financial information derived from recent experience of IFRS convergence in India and support practice of phased IFRS convergence and decision to exempt unlisted companies having net worth lower than Rs. 2.50 billion from IFRS convergence

\subsection{First Time Adoption of Ind AS and Differences in Equity}

IFRS 1 First time adoption of Ind ASs (Ind AS 101) provides mandatory and optional exemptions from retrospective application of new standards to facilitate less costly change over except that Ind AS 101 grants two critical exemptions -

1. Carrying amount of property, plant and equipment, intangible assets and investment property under the previous GAAP can be treated as deemed cost under Ind ASs; and

2. Carrying amount of the long-term foreign currency denominated monetary items can be carried forward in Ind AS and the accounting policy of deferral of exchange fluctuation difference if opted under the previous GAAP can be continued.

Sample companies exercised these exemptions which reduces the gap between Ind AS and IGAAP equity. Ind AS transition reconciliation statement provides useful information about the differences in equity as per the IGAAP and Ind AS. The sample companies presented the reconciliation in two different ways - some companies have presented only reconciliation of balance sheet items but most of the companies have presented reconciliation of both balance sheet items as well as separate equity reconciliation by major issues. Major issues of equity reconciliation on the date of transition and reporting date of the comparative period as disclosed by the sample companies in the transition reconciliation statement are presented in Table 2.

Table 2. Major issues in equity reconciliation in Ind AS application

\begin{tabular}{|c|c|c|c|}
\hline Sl. No. & & Major issue in equity reconciliation & $\begin{array}{l}\text { Applicable } \\
\text { standards }\end{array}$ \\
\hline \multirow[t]{15}{*}{1} & & Fair valuation of financial assets and financial liabilities & Ind AS 109 / IFRS \\
\hline & i. & Fair valuation of FVTOCI equity investments & \\
\hline & ii. & Fair valuation of FVTOCI debt investments & \\
\hline & iii. & Fair valuation of FVTPL financial assets and financial & \\
\hline & & liabilities & \\
\hline & iv. & Amortized cost valuation of security deposit & \\
\hline & v. & Amortized cost valuation of employee loan & \\
\hline & & Amortized cost measurement of financial assets and & \\
\hline & & financial liabilities & \\
\hline & vi. & $\begin{array}{l}\text { Adjustment of transaction costs, premium and discount in } \\
\text { amortized cost measurement }\end{array}$ & \\
\hline & vii. & Fair valuation of financial guarantee & \\
\hline & viii. & Discounting effect on deferred liabilities & \\
\hline & ix. & Fair valuation of derivatives & \\
\hline & $\mathrm{x}$. & Impact of discounting long term contractual obligations & \\
\hline & xi. & Discounting of retention money & \\
\hline
\end{tabular}


xii. Time value of forward contract

xiii. $\quad$ Fair valuation of advances

Ind AS 32 / IAS 32

xiv. Fair valuation of preference shares

xv. Fair value measurement of optionally convertible

debentures

2

Impairment of financial assets

Ind AS 109 / IFRS

Effect of expected credit loss on trade receivables

9

Provisions

Ind AS 37/

i. Discounting provisions

IAS 37

ii. Unwinding of discount on provision

iii, Decommissioning liability

iv Mine closure provisions

4

Employee share based payment

Ind AS 102/

Impact of fair value measurement

IFRS 2

5

Treasury shares

Ind AS 32/

i. Change in measurement of treasury shares

IAS 32

ii. Adjustment of shares held by trusts

Joint Ventures

Ind AS 28/

Change in accounting from proportionate consolidation to

IAS 28

equity method

Business Combinations

Ind AS 103/ IFRS

i.

Expensing acquisition costs

3

ii. Retrospective effect on business combination

iii. Discounting contingent consideration

iv. Restatement of result due to merger

8

Subsidiary

Ind AS 110/

i. Change in non-controlling interest

IFRS 10

ii. Change in status of subsidiary due to definition of control

9

Property, Plant and Equipment

Ind AS 16/

i. $\quad$ Fair valuation of PPE

IAS 16

ii. Capitalization of stores and spares and depreciation

iii. Spare accounting

10

Intangible assets

Ind AS 38/

i. Reversal of amortization of right of way

IAS38

ii. Recognition of intangible assets not eligible to be

iii. Recognized under the IGAAP

iv. Reversal of goodwill amortization

11

Leases

Ind AS 17/

i. Reclassification of leasehold land

IAS 17

ii. Amortization of prepaid lease rentals 
12

13

$$
\begin{aligned}
& \text { i. } \\
& \text { ii. } \\
& \text { iii. }
\end{aligned}
$$

4

5

\section{Government Grants}

Impact of reclassification of government grants

Ind AS 20/

IAS 20

Ind AS 18/

IAS 18

$$
\text { Impact of service concession arrangement }
$$

Provisioning for customer loyalty programs

Impact of advance on revenue recognition
Reversal of proposed dividend and dividend distribution tax

Adjustment of Prior period items

Adjustments to deferred tax
Ind AS 10/

IAS 10

Ind AS 8/

IAS 8

Ind AS 12/

IAS 12

Wide-ranging adjustments items affected IGAAP equity of the sample companies differently. Ind AS adjustments as $\%$ of IGAAP equity ( $\Delta \mathrm{E} 2015 \%$ ) fall in the range $-24.8 \%$ to $85.46 \%$ with median of $3.73 \%$, and $\Delta \mathrm{E} 2016 \%$ falls in the range of $-34.36 \%$ to $113.93 \%$ with median of $3.1 \%$. However, volatility of $\Delta \mathrm{E} 2015 \%$ and $\Delta \mathrm{E} 2016 \%$ remained stable at $17.99 \%$ and $16.84 \%$ respectively. However, positive value of $\Delta \mathrm{E} 2015$ (Rs. 1158.59 billion) and $\Delta \mathrm{E} 2016$ (Rs.1078.09 billion) signify that as a whole IFRS convergence had positively impacted equity of companies. So IGGAP measures appeared more conservative than Ind AS (IFRS converged set of standards). Presented in Figure 1 is the comparative IGAAP and Ind AS equity which are subjected to analysis under Research Hypothesis 1 whether mean of differences between IGAAP and Ind AS equity is significant.

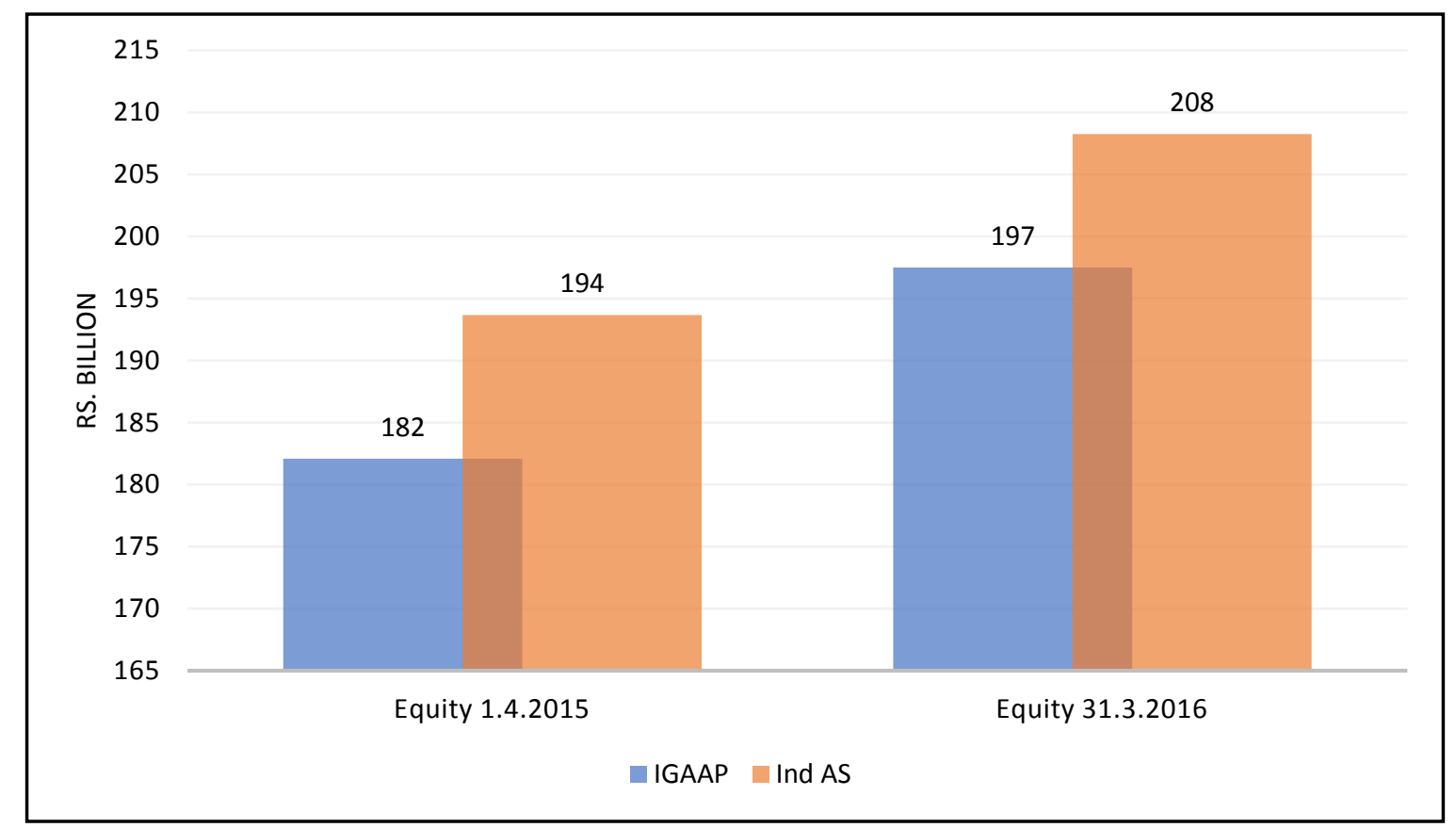

Figure 1. Average Equity under IGAAP and Ind AS

\subsection{Profit and Other Comprehensive Income}

Income measurement based on comprehensive income comprising of both realized and unrealized fair value gain/loss is an alternative way of looking into performance of an entity. TCI comprises of PAT reflecting managerial performance and OCI reflecting primarily changes in market factors. Realized gains and losses are included in traditional profit measurement along with unrealized gains/losses on fair value through profit or loss (FVTPL) financial assets and financial liabilities and foreign currency monetary items. But evaluation of unrealized gain /loss 
on long term assets and liabilities would demonstrate whether any significant gain/loss is expected in future. Primarily, OCI can help users to understand impact of fair value gain/loss on long term assets and liabilities.

While it is difficult to define other comprehensive income since various items listed as OCI in IAS 1 Presentation of Financial Statements do not have any homogenous characteristics, list of other comprehensive income underpins the inherent unrealized fair value gain/loss on non-current assets and liabilities, cash flow hedges on which the hedged item remained unrecognized on the balance sheet date, impact of exchange rate on foreign operations and change in actuarial assumptions. However, IFRS classifications of gain or loss of FVTOCI equity or debt investments as OCI but fair value gain or loss on investment property as an item of profit or loss impair homogenous characteristics of OCI items.

Also, Ind AS expansion of the OCI list by inclusion of bargain purchase gain in business combinations breaks down the unrealized fair value gain characteristics since realized fair value gain on completed business combinations transaction is classified as an OCI item. Fair value carve out of investment property impairs fair value application to the entities holding investment property as an alternative investment. While equity and debt instruments are allowed to be classified either as FVTPL or FVTOCI, a fair performance measurement mechanism would require similar accounting treatment to investment property. Presented below in Table 3 is the list of OCI items reported by the sample companies which explains only $29.87 \%$ of difference between IGAAP profit and Ind AS total comprehensive income.

Table 3. List of Items of Other Comprehensive Income

\begin{tabular}{|c|c|c|c|}
\hline & Abbreviations & $\begin{array}{l}\text { No. of } \\
\text { Reporting } \\
\text { Companies }\end{array}$ & $\begin{array}{c}\text { OCI } \\
2015-16 \\
\text { Rs. in Billion }\end{array}$ \\
\hline $\begin{array}{l}\text { 1. Remeasurement gain/ loss on defined } \\
\text { benefit plans }\end{array}$ & DBO & 99 & 54.18 \\
\hline $\begin{array}{l}\text { 2. Gain/loss Equity investments classified as } \\
\text { fair value through other comprehensive } \\
\text { income }\end{array}$ & FVTOCIE & 46 & -126.74 \\
\hline $\begin{array}{l}\text { 3. Gain/loss other financial assets classified } \\
\text { as fair value through other comprehensive } \\
\text { income }\end{array}$ & FVTOCIA & 15 & 0.42 \\
\hline 4. Cash Flow Hedge Reserve & CFHR & 33 & -10.37 \\
\hline 5. Deferred gain / loss on investment hedge & DGIH & 2 & -7.14 \\
\hline $\begin{array}{l}\text { 6. Translation difference in Foreign } \\
\text { Operations }\end{array}$ & TDFO & 65 & 86.22 \\
\hline $\begin{array}{l}\text { 7. Translation difference in Long term } \\
\text { Foreign currency monetary items (TDFCMI) }\end{array}$ & TDFCMI & 2 & -1.62 \\
\hline $\begin{array}{l}\text { 8. Share of OCI in associates and joint } \\
\text { ventures }\end{array}$ & SOCI & 36 & 1.42 \\
\hline $\begin{array}{l}\text { 9. Income tax on OCI items (presented } \\
\text { separately) }\end{array}$ & ITOCI & 88 & -19.06 \\
\hline 10. Other Items & & & -8.11 \\
\hline Other comprehensive income & & & -30.80 \\
\hline Other Ind AS adjustments & & & -72.29 \\
\hline $\mathrm{OCI} / \mathrm{TCI} \%$ & & & $-1.12 \%$ \\
\hline Other Ind AS Adjustments / TCI \% & & & $-2.74 \%$ \\
\hline
\end{tabular}


Analysis of difference between profit as per IGAAP and Ind AS of 100 sample companies for the comparative period (i.e. accounting period 2015-16) shows that profit and TCI as per Ind AS were negatively impacted of which OCI adjustments accounted for $-1.12 \%$ and other Ind AS adjustments accounted for $-2.74 \%$. Frequency of adjustments arising out of various OCI components is presented in Figure 2.

A survey of frequency of occurrence OCI elements of sample companies in 2016-17 (Figure 2) showed that out of various elements of OCI only nine elements are reported by the sample companies:

(1) Remeasurement of Defined Benefit Plan (RDBP) is common in the sample companies. It shows adjustment for actuarial gain covers $31.31 \%$ of negative OCI elements.

(2) $65 \%$ of the sample companies reported Translation difference in foreign operations (TDFO) and a significant positive translation gain has been reported which offset $49.82 \%$ negative OCI elements. A significant fair value loss has been reported on long term equity investments despite positive movement in Indian stock market indices.

(3) Fair value gain or loss on equity investments through other comprehensive income (FVTOCIE) is reported by $46 \%$ companies, while fair value gain or loss on other financial assets through other comprehensive income (FVTOCIA) is reported by only $15 \%$ companies;

(4) Cash flow hedge reserve (CFHR) is reported by 33\% companies while Deferred gain / loss on investment hedge (DGIH) is reported by only $2 \%$ companies. Further negative cash flow hedge reserve would require further analysis of the efficacy of hedging methods.

(5) Share of OCI of associate companies or joint ventures (SOCI) are reported by $36 \%$ companies which signifies strong presence of associates and joint ventures.

(6) Infrequently reported elements of OCI are Translation difference on long term Foreign currency monetary items (TDLFCMI), Bargain purchase gain (BPG), OCI of discontinued Operations (OCIDO);

(7) Income-tax impact on OCI elements (ITOCI) are separately presented by $88 \%$ of the sample companies.

The above analysis (Table 3 ) indicates that OCI adjustments were offsetting by nature and did not substantially impactTCI.

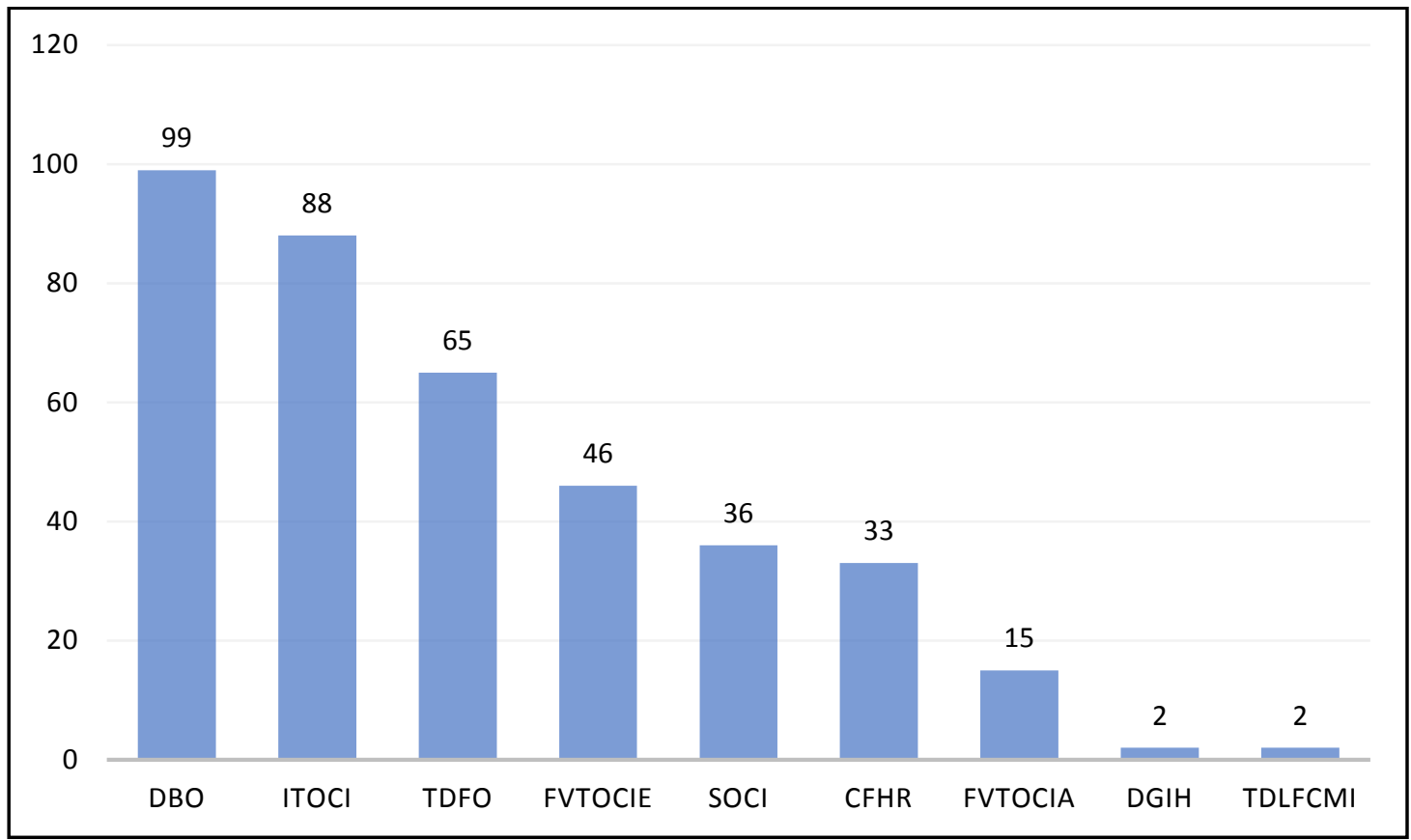

Figure 2. OCI By reporting companies 
Although OCI and other Ind AS adjustments resulted in negative adjustments during the comparative period 2015-16, first -time adoption adjustments had positive impact reflecting positive difference of Ind AS equity over IGAAP equity. However, negative profit difference between Ind AS and IGAAP profit is subject matter of Research Hypothesis 2 whether such profit difference is significant. Presented below in Figure 3 is the aggregate profit of sample companies as per IGAAP and Ind AS.

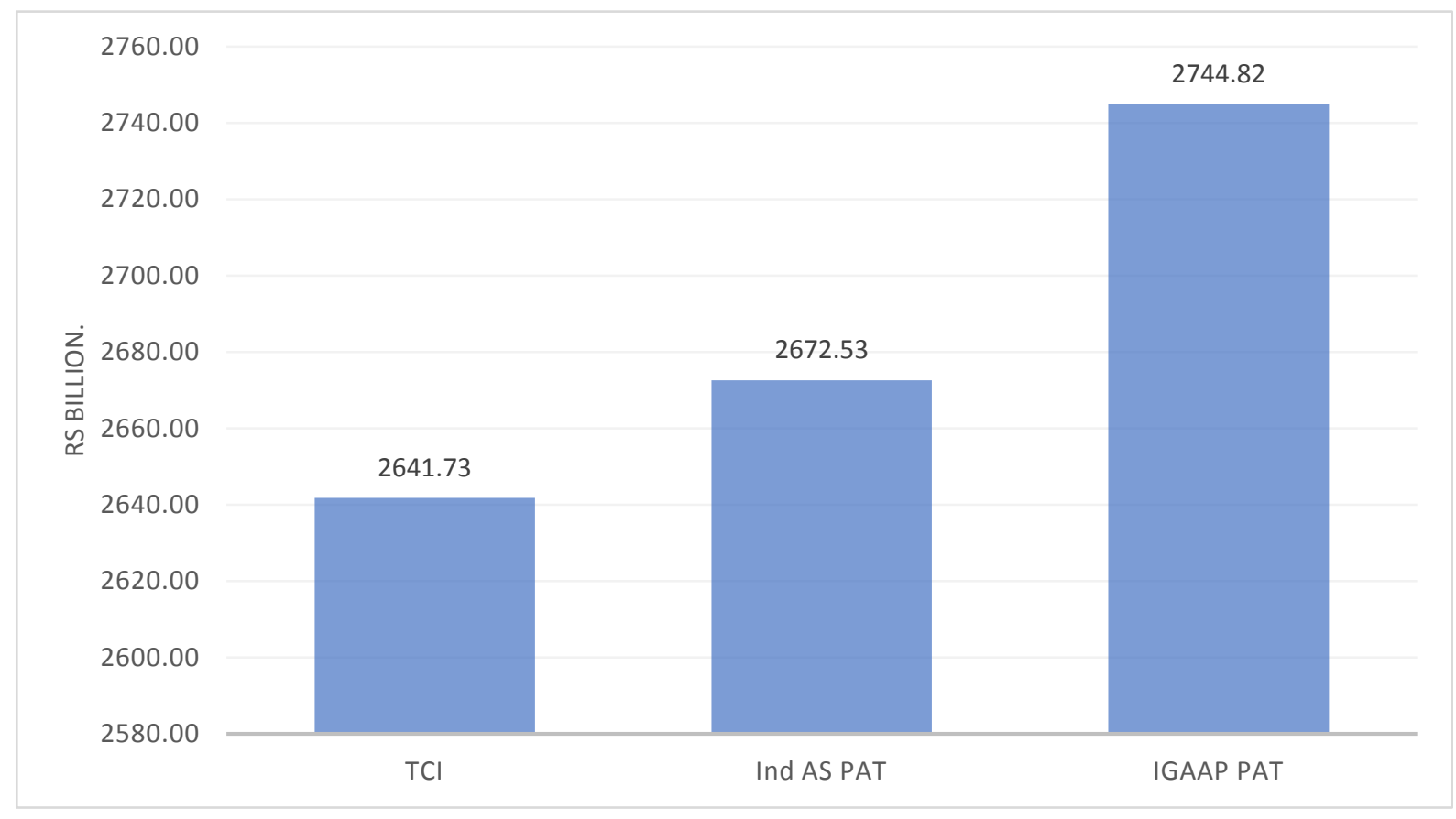

Figure 3. Comparison of Profit Measures 2015-16

In this research study, analyses are carried out based on first set of Ind AS based consolidated financial statements 2016-17 of 100 listed companies covering BSE SENSEX, NITFY, NIFTY Next 50 companies. Relevant data are sourced manually from published financial statements of the sample companies.

Paragraph 2 contains literature review highlighting three streams of research studies relating to IFRS implementation. Paragraph 3 details out research methodology including research hypotheses and brief discussion of the statistical methods used for data analysis. Paragraph 4 covers analysis of result, and Paragraph 5 presents summary and conclusions.

\section{Literature Review}

IFRS adoption triggered three streams of empirical research covering financial reporting effects, capital market effects and macroeconomic effects. The current paper fall in the first category i.e. financial accounting effect. In this category, research studies primarily cover (a) compliance with the IFRS and the accounting choices, (b) analysis of properties of accounting numbers, and (c) value relevance. For example, Schadewitz and Vieru (2007), Costel (2013), Kabir et al (2016) find increased value relevance of financial reporting after IFRS adoption, while Callao et al. (2007), Filip and Raffournier ( 2010), Dobija and Klimczak ( 2010), Terzi (2013), Aledo and Abellan (2014) and Piotr (2014) document a decline in relevance of financial reporting. Arshad et al (2016) found that size of entity matters in IFRS adoption implications.

Callao et al (2007) found no improvement in the relevance of financial reporting to local stock market operators because the gap between book and market values widens when IFRS are applied. In a different study of IFRS impact on various EU countries, Callao (2009) found that the first application of IFRS had different effects on the financial reporting among countries and grouped various EU countries on the basis of impact but concluded that IFRS is a different accounting system when compared to previous GAAP accounting numbers. Based on data of 135 Australian entities, Goodwin and Ahmed (2006) observed that more than half of small firms have no change in net income or 
equity from A - IFRS, and that there is an increase in the number of adjustments to net income and equity with firm size.

Maria (2015) studied impact of the IFRS adoption on financial assets and liabilities of Romanian listed companies measured through a set of twenty -three ratios and found that fourteen of the twenty -three ratios (more than 60\%) record changes that range from $-5 \%$ to $+5 \%$, which was interpreted (applying mean index of comparability scale) as a neutral impact of IFRS implementation. Romana (2014) found (based on a sample of sixty-seven Romanian companies) that the application of IFRS had a small effect on net income and shareholders' equity. Dobija (2010) found positive evidence of value relevance (based on sample from Warsaw Stock Exchange in Poland) but no improvement in the strength of the relationship over time. Terzi et al (2013) did not observe statistically significant difference in book value/market value ratio analysis depending on the market value under local GAAP and IFRS. However, in subsector analysis, they identified that some subsector groups have been affected by the IFRS transition. Based on data of banks listed on the Warsaw Stock Exchange during 1998-2012, Piotr (2014) observed that increase in the value relevance of both book values of equity and residual incomes of banks after introduction of IFRS is statistically insignificant. Aledo and Abellan (2014) found no evidence of increased value relevance after IFRS adoption in Spain.

\section{Research Methodology}

To evaluate significance of Ind AS adjustments two research hypotheses are developed based on preliminary investigation presented in Paragraphs 1.2 and 1.3.

Research hypothesis 1: Change in equity arising out of first time adoption of Ind AS is not significant

Change in equity is measured taking the difference between IGAAP equity and Ind AS equity on the date of transition to Ind AS, i.e. 1 April 2015 and reporting date of the comparative period to the first Ind AS compliant financial statements, i.e. 31 March 2016. Given that -

$\triangle \mathrm{E} 15_{\mathrm{i}}=\mathrm{IGAAPE}_{1} 5_{\mathrm{i}}-\mathrm{INDASE}_{1} 5_{\mathrm{i}}$; and

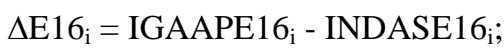

Where $\Delta \mathrm{E} 15_{\mathrm{i}}$ and $\Delta \mathrm{E} 16_{\mathrm{i}}$ are differences between IGAAP equity and Ind AS equity on the date of transition to Ind AS, i.e. 1 April 2015 and on comparative period reporting date, i.e. 31 March 2016 respectively;

IGAAPE15 $5_{i}$ and IGAAPE16 $6_{i}$ are equity as per previous Indian GAAP on the date of transition and comparative period reporting date respectively;

INDASE15 $5_{i}$ and INDASE16 $6_{i}$ are equity as per Ind AS on the date of transition and comparative period reporting date respectively.

Null Hypothesis $\left(\mathrm{H}_{0}\right): \quad \Delta \mathrm{E} 15_{\mathrm{i}}=0$, and $\Delta \mathrm{E} 16_{\mathrm{i}}=0$;

Alternative Hypothesis $\left(\mathrm{H}_{1}\right): \Delta \mathrm{E} 15_{\mathrm{i}} \neq 0$, and $\Delta \mathrm{E} 16_{\mathrm{i}} \neq 0$.

Research Hypothesis 2 Change in profit arising out of first time adoption of Ind AS is not significant

Change in profit is measured as the difference between profit as per IGAAP and total comprehensive income as per Ind AS during the comparative period, i.e. 2015-16.

$\Delta \mathrm{P} 16_{\mathrm{i}}={\text { IGAAPP } 16_{\mathrm{i}}-\text { INDASTCI16 }}_{\mathrm{i}}$

where $\Delta \mathrm{P} 16_{\mathrm{i}}=$ Difference between IGAAP profit and total comprehensive income as per Ind AS equity during the comparative period 2015-16;

IGAAPP16 $6_{i}=$ Profit after tax as per IGAAP for the period 2015-16;

INDASTCI16 $6_{\mathrm{i}}=$ Total comprehensive income as per Ind AS for the period 2015-16;

Null Hypothesis $\left(\mathrm{H}_{0}\right): \quad \Delta \mathrm{P} 16_{\mathrm{i}}=0$.

Alternative Hypothesis $\left(\mathrm{H}_{1}\right): \Delta \mathrm{P} 16_{\mathrm{i}} \neq 0$

Some of the Ind ASs are substantially different from IGAAP while other Ind ASs have minor differences, and therefore significance of change in equity and profit depends on nature of assets and liabilities of companies subjected to Ind AS adoption. For example, Ind AS 109 Financial Instruments is substantially different AS 13 Accounting for Investments of the IGAAP. Companies having significant amount of financial assets and financial liabilities would have significant equity and profit adjustments. Similarly, there exists differences in depreciation charge of property, plant and equipment applying componentization, capitalization of major spares, classification of 
land lease, amortization of intangible assets having indefinite useful life, and method of consolidation of joint ventures requiring switching over from proportionate consolidation to equity method accounting. Thus various companies are expected to be differently impacted by IFRS convergence. These research hypotheses have been designed to evaluate if the changes in equity and profit arising out of first time adoption of Ind ASs are significant. This would help the policy maker as well as the users to appreciate the value relevance of IFRS convergence.

In an earlier research work Ghosh ( 2017) found that ratios of OCI/ Ind AS Profit and OCI/TCI are not significantly different which signifies that impact of OCI arising out of IFRS convergence is not significant. It is also found that ratios of IGAAP equity to market capitalization and IND AS equity to market capitalization are not significantly different which implies that book to market ratio does not significantly differ. In this paper, it is attempted to re-verify whether equity and profit are significantly different although certain ratios are not significantly different. These research hypotheses take into account change in equity and profit rather than ratios of equity and profit.

To test Research Hypotheses $1 \& 2$ paired sample t-set is applied as Ind AS equity and profit are derived applying Ind AS adjustments to IGAAP equity and profit. Paired sample t-test compares two means which typically represent same object one before intervention and the other after intervention. The purpose of the test is to determine whether there is statistical evidence that the mean difference between paired observations on a particular outcome is significantly different from zero.

For the purpose of applying paired sample t-test, outliers ${ }^{3}$ in equity difference series, $\Delta \mathrm{E} 16_{\mathrm{i}}$ and $\Delta \mathrm{E} 16_{\mathrm{i}}$, and profit difference series, $\Delta \mathrm{P} 16_{\mathrm{i}}$ are identified applying weighted quartile difference. It is found that $20 \%$ of the data in each series fall outside Upper and Lower Bound based and therefore it is considered that elimination of the outliers would distort the randomness of the data series. So original data series are tested for normality applying Shapiro-Wilk test in SPSS. It is found that $\Delta \mathrm{E} 16_{\mathrm{i}}, \Delta \mathrm{E} 16_{\mathrm{i}}$ and $\Delta \mathrm{P} 16_{\mathrm{i}}$ series are normally distributed and thus satisfy the pre-condition for paired sample t-test. Since $\mathrm{p} \leq 0$, applying Shapiro -Wilk statistics null hypothesis that the distributions, $\Delta \mathrm{E} 15$, $\Delta \mathrm{E} 16$ and $\Delta \mathrm{P} 16$ are normally distributed, cannot be rejected.

\section{Research Hypothesis 3 : Changes in equity and profit are impacted by size of IGAAP equity}

This research hypothesis is intended to verify if Ind AS impact has any linear relationship with the size of the equity investment. Phased Ind AS implementation has the underlying assumption that companies having net worth of Rs. 5.00 billion and above might have comparatively higher impact than companies having net worth level below that.

Null Hypothesis : Change in equity arising out of Ind AS implementation is correlated to size of equity.

Alternative Hypothesis : Change in equity is not size dependent.

This is verified applying multiple regression analysis using size of equity as independent variable.

The following multiple regression equation is designed to test the influence of size on equity difference :

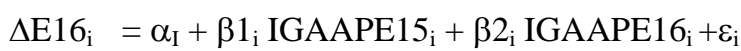

Dependent variables IGAAPE15 $5_{\mathrm{i}}$ and IGAAPE16 ${ }_{\mathrm{i}}$ are used as proxy to size of companies that are expected to influence change in equity.

Table 4. Normality of Equity and profit differences

\begin{tabular}{lcccccc}
\hline & \multicolumn{2}{c}{ Kolmogorov-Smirnov $^{\mathrm{a}}$} & \multicolumn{3}{c}{ Shapiro-Wilk } & \\
& Statistic & Df & $\mathrm{p}$ & Statistic & Df & $\mathrm{p}$ \\
\hline$\Delta \mathrm{E} 15$ & .311 & 100 & .000 & .569 & 100 & .000 \\
$\Delta \mathrm{E} 16$ & .229 & 100 & .000 & .659 & 100 & .000 \\
$\Delta \mathrm{P} 16$ & .269 & 100 & .000 & .630 & 100 & .000 \\
a. Lilliefors Significance Correction & & & & & \\
\hline
\end{tabular}




\section{Findings}

\subsection{Research Hypotheses $1 \& 2$}

Presented below in Table 5(a) and 5(b) are summarised results of paired sample t-tests. Paired Samples Correlations in Table 5(a) show the bivariate Pearson correlation coefficient (with a two-tailed test of significance) for each pair of variables is strongly and positively correlated.

Significant average difference is found between IGAAPE15 and INDASE15 $\left(\mathrm{t}_{0-2.896}, \mathrm{p} \leq 0.05\right)$, and IGAAPE16 and INDASE16( $\left.\mathrm{t}_{0-2.261}, \mathrm{p} \leq 0.05\right)$, and on an average, IGAAP equity was lower than Ind AS equity. Thus the null hypothesis that difference between IGAAP and Ind AS equity on the date of transition and on the end date of the Ind AS comparative period is not significant is rejected since the 2-tailed significance (which $p$ value in SPSS) is less than 0.5 .

However, significant average difference is not found between IGAAP profit and Ind AS total comprehensive income $\left(\mathrm{t}_{0.509}, \mathrm{p}>.05\right)$, and on an average, IGAAP profit is higher than Ind AS total comprehensive income. Thus the null hypothesis that difference between IGAAP profit and Ind AS total comprehensive income is not significant is retained since the 2-tailed significance is greater than 0.5.

Table 5(a). Paired Samples Correlations

\begin{tabular}{llrrr}
\hline & & $\mathrm{N}$ & Correlation & \multicolumn{2}{c}{ Sig. } \\
\hline Pair 1 & IGAAPE15 - INDASE15 & 100 & .992 & .000 \\
Pair 2 & IGAAPE16- INDASE16 & 100 & .993 & .000 \\
Pair 3 & IGAAPP16- INDASTCI16 & 100 & .967 & .000 \\
\hline
\end{tabular}

Table 5(b). Paired Sample t-test

\begin{tabular}{|c|c|c|c|c|c|c|c|c|c|}
\hline & & \multicolumn{5}{|c|}{ Paired Differences } & \multirow[t]{3}{*}{$\mathrm{t}$} & \multirow[t]{3}{*}{ Df } & \multirow{3}{*}{$\begin{array}{l}\text { Sig.(2- } \\
\text { tailed) }\end{array}$} \\
\hline & & \multirow[t]{2}{*}{ Mean } & \multirow[t]{2}{*}{$\begin{array}{c}\text { Std. } \\
\text { Deviation }\end{array}$} & \multirow[t]{2}{*}{$\begin{array}{l}\text { Std. } \\
\text { Error } \\
\text { Mean }\end{array}$} & \multicolumn{2}{|c|}{$\begin{array}{l}\text { 95\% Confidence } \\
\text { Interval of the } \\
\text { Difference }\end{array}$} & & & \\
\hline & & & & & Lower & Upper & & & \\
\hline Pair 1 & $\begin{array}{l}\text { IGAAPE15 - } \\
\text { INDASE15 }\end{array}$ & -1189.95 & 4109.33 & 410.93 & -2005.33 & -374.57 & -2.896 & 99 & .005 \\
\hline Pair 2 & $\begin{array}{l}\text { IGAAPE16- } \\
\text { INDASE16 }\end{array}$ & -973.49 & 4305.42 & 430.54 & -1827.79 & -119.21 & -2.261 & 99 & .026 \\
\hline Pair 3 & $\begin{array}{l}\text { IGAAPP16- } \\
\text { INDASTCI16 }\end{array}$ & 66.99 & 1316.43 & 131.64 & -194.21 & 328.20 & .509 & 99 & .612 \\
\hline
\end{tabular}

Thus in the case of Pairs 1 and $2, \mathrm{p} \leq 0.05$ and therefore null hypotheses that $\Delta \mathrm{E} 15_{\mathrm{i}}=0, \quad$ and $\Delta \mathrm{E} 16_{\mathrm{i}}=0$ are rejected but in the case of Pair $3, \mathrm{p} \geq 0.05$ and so null hypothesis that $\Delta \mathrm{P} 16_{\mathrm{i}}=0$ is retained.

Non-parametric Wilcoxon Signed Rank test is applied as additional statistical tool to evaluate the significance of equity and profit differences. Results are presented in Appendix I. In accordance with Wilcoxon Signed Rank test, null hypotheses that 'median of differences between IGAAP equity and Ind AS equity are equal' is rejected. But the null hypothesis that 'median of differences between IGAAP profit and Ind AS total comprehensive income' is retained. The results of parametric paired sample t-test and non-parametric Wilcoxon Signed Rank test are found to be consistent.

The resultant significant positive equity difference arising out of IFRS convergence signifies cumulative impact of differential accounting treatments of Ind ASs and IGAAP, and that equity has been positively impacted. Ind AS carve outs (Paragraph 1.1, carve outs 1 and 2) did not have off -setting impact. In fact, only $2 \%$ of sample companies were impacted by carve out of long -term foreign currency monetary items. Data showing impact of the carve out relating to IGAAP carrying amount of property, plant and equipment, intangible asset and investment property as deemed cost as per Ind AS is not available. However, profit difference has been analyzed for the comparative period, and impact of Ind ASs on revenue and expenses appears to be not significant given that 
transitional differences are accounted for in retained earnings and other fair value reserves. It is also found that impact of OCI items (Table 3) is not significant ( Ghosh,2017).

\subsection{Research Hypothesis 3}

Findings of multiple regression are presented in Tables 6(a)-(c) below:

Table 6(a). Correlation analysis

\begin{tabular}{llrrr}
\hline Model & R & R Square & Adjusted R Square & $\begin{array}{c}\text { Std. Error of the } \\
\text { Estimate }\end{array}$ \\
\hline 1 & $.758^{\mathrm{a}}$ & .575 & .566 & 4053.47 \\
\hline
\end{tabular}

Table 6(b). ANOVA ${ }^{\mathrm{a}}$ Table

\begin{tabular}{rlrrrrr}
\hline \multicolumn{1}{l}{ Model } & \multicolumn{1}{l}{ Sum of Squares } & \multicolumn{1}{c}{ Df } & \multicolumn{1}{c}{ Mean Square } & \multicolumn{1}{c}{ F } & \multicolumn{1}{c}{ Sig. } \\
\hline \multirow{3}{*}{1} & Regression & 2156041365.34 & 2 & 1078020682.67 & 65.611 & $.000^{\mathrm{b}}$ \\
& Residual & 1593768541.28 & 97 & 16430603.52 & & \\
& Total & 3749809906.62 & 99 & & & \\
\hline
\end{tabular}

a. Dependent Variable: $\Delta \mathrm{E} 16$

Table 6 (c). Coefficients ${ }^{\mathrm{a}}$ Table

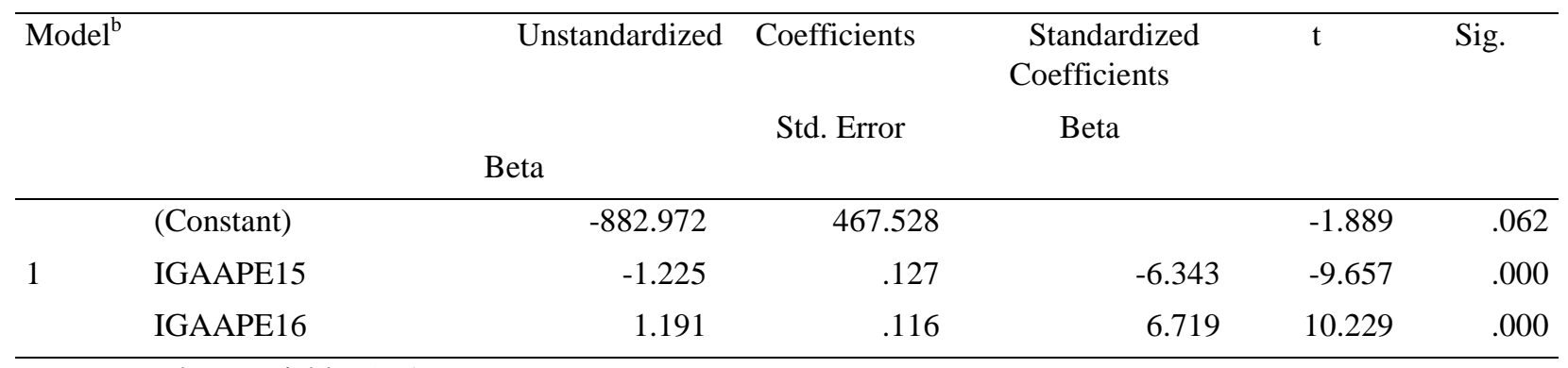

a. Dependent Variable: $\triangle \mathrm{E} 16$

b. Predictors: (Constant), IGAAPE16, IGAAPE15

Size of the equity explains $57.5 \%$ of equity difference. Since $F(2,97)=65.611, p<0 \quad, R^{2}=0.575$, both the variables are added statistically significantly to the prediction of equity difference. Regression coefficients of IGAAPE15 and IGAAPE16 are significant except for the constant. It is thus observed that size of equity on the date of transition and on comparative reporting date are important determinants of equity difference and so phased implementation of Ind AS has rationale. And also exemption to unlisted companies having net worth below Rs. 2.5 billion is justified. However, impact of IFRS convergence on smaller sized company should be effectively substantiated using first set of Ind AS based financial statements of Phase II companies.

\section{Summary and Conclusions}

Empirical analyses of this paper show that Ind AS has significant negative impact on equity and also size of equity appears to be a determinant factor to equity difference during the comparative period. But no significant difference in profit has been found. Differences in profit and equity perhaps depend on nature of financial statements elements which in turn depends on applicability of various Ind ASs and comparative differences in IGAAP and Ind ASs. Therefore, it requires analysis of equity difference by nature of assets and liabilities rather than simply by size of equity. Hence scope of further research is found in terms of evaluating differences in non-current and current assets, liabilities, revenue and expenses, and also differences in widely used financial ratios. Also further research should be carried out to validate the findings based on first set of financial statements of Phase II companies as well as of financial institutions.

The limitation of the paper is that it did not attempt to evaluate whether Ind AS based accounting numbers would be better estimator of equity price and reduce the gap between market to book value which are considered as stronger indicators of value relevance of IFRS. Also, the current research did not link components of OCI items to equity price which could identify the critical fair value factors. 


\section{End Notes}

1. IGGAP is the previous GAAP notified as per the Companies (Accounting Standards) Rules 2006. IGGAP became effective for accounting periods commencing on or after $7^{\text {th }}$ December 20006.

2. Indian Accounting Standards are IFRS converged set of accounting standards that carry same paragraphs with certain carve outs. IFRIC and SIC Interpretations are included as Appendix to the appropriate standards. These standards are notified under the Companies Act 2013 of India with a timeline for implementation as per the Roadmap notified by the Ministry of Corporate Affairs, Government of India. In the Phase 1 i.e. for the accounting period commencing on or after 1 April 2016 with comparative period ending on 31 March 2016, the Ind ASs become applicable to the following companies for the preparation and presentation of financial statements:

- Companies whose equity or debt securities are listed or are in the process of listing on any stock exchange in India or outside India (listed companies) and having net worth of Rs.5.00 billion or more;

- Unlisted companies having a net worth of Rs.5.00 billion or more

- Holding, subsidiary, joint venture or associate companies of the listed and unlisted companies covered above.

This research is based on first set of consolidated inancial statements along with reconciliation of equity and profit as per IGAAP and Ind AS. IGAAP is previous GAAP of India notified by virtue of Companies (Accounting Standards) Rules 2006 as amended from time to time

In the Phase II i.e. for the accounting period commencing on or after 1 April 2017 with comparative period ending on 31 March 2017, the Ind ASs become applicable to the following companies for the preparation and presentation of financial statements:

- Companies whose equity or debt securities are listed or are in the process of listing on any stock exchange in India or outside India (listed companies) and having net worth of less than Rs.5.00 billion or more;

- Unlisted companies having a net worth of Rs.2.50 billion or more but less than Rs. 5.00 billion

- Holding, subsidiary, joint venture or associate companies of the listed and unlisted companies covered above.

Roadmaps for Scheduled commercial banks (excluding RRBs) and insurers/insurance companies

Mandatory application of Ind AS for the accounting period commencing on or after 1 April 2018 with comparative period ending on 31 March 2018 by

- Scheduled commercial banks excluding regional rural banks and all India term-lending and refinancing institutions;

- Non-banking finance companies having net worth of Rs. 5.00 billion and above; and

- Holding, subsidiary, joint venture or associate companies of scheduled commercial banks.

Mandatory application of Ind AS for the accounting period commencing on or after 1 April 2019 with comparative period ending on 31 March 2019 by

- All non-banking finance companies whose equity and/or debt securities are listed or are in the process of listing on any stock exchange in India or outside India and having a net worth less than Rs. 5.00 billion;

- NBFCs that are unlisted companies, having a net worth of Rs. 2.50 billion or more but less than Rs. 5.00 billion;

- Holding, subsidiary, joint venture or associate companies of companies covered above, other than those companies already covered under the corporate roadmap.

Adoption of Ind ASs by insurance companies is deferred till 2020-21 to give effect to IFRS 17 Insurance contracts.

3. Outliers are identified as data falling outside upper and lower bound.

Lower bound $=($ Quartile $1-$ Quartile difference $) \times 1.5$

Upper bound $=($ Quartile $3+$ Quartile difference $) \times 1.5$.

It is found that $20 \%$ of the data in each series fall outside Upper and Lower Bound and therefore elimination of the outliers would distort the randomness of the data series. So original data series are tested for normality applying Shapiro-Wilk test in SPSS. 


\section{References}

Aledo, J.M. \& Abellan, M.D. (2014). The value relevance of accounting numbers under IFRS. Australian Accounting Review, 24(3), 237-254. https:// doi.org/10.1111/auar.12043

Arshad A., Saeed A., Phillip O. \& Syed Z.A.S. (2016). The Impact and Implications of International Financial Reporting Standards in the United Kingdom: Evidence from the Alternative Investment Market. Australian Accounting Review, 26(4), December, 360-375

Callao, S., Jarne, J. I., \& Lainez, J. A. (2007). Adoption of IFRS in Spain: effect on the comparability and relevance of financial reporting. Journal of International Accounting, Auditing and Taxation, 16(2), 148-178. https://doi.org/10.1016/j.intaccaudtax.2007.06.002

----- (2009). The impact of IFRS on the European Union: is it related to the accounting tradition of the countries? Journal of Applied Accounting Research, 10(1), 33-55. https://doi.org/10.1108/09675420910963388

Costel I. (2013). Impact of IFRS on accounting data - Gary index of conservatism applied to some European listed companies. Scientific Annals of the "Alexandru Ioan Cuza" University of Iaşi Economic Sciences, 60(2), 1-19, https://doi 10.2478/aicue-2013-0023

------ (2014). Impact of IFRS on the accounting numbers of Romanian listed companies. Accounting and Management Information Systems, 13(3), 466-491.

Cordazzo, M. (2013). The impact of IFRS on net income and equity: evidence from Italian listed companies. Journal of Applied Accounting Research, 14(1), 54-73. https://doi.org/10.1108/09675421311282540

Dalc1 I., \& Özyapıc1 H. (2017). Analysis of the impact of first-time mandatory IFRS adoption on financial statements: The case study of the listed hotels in Turkey. Accounting and Management Information Systems, 16(1), 5-29. https://doi.org/10.24818/jamis.2017.01001

Dobija, D. \& Klimczak, K.M. (2010). Development of accounting in Poland: Market efficiency and the value relevance of reported earnings. The International Journal of Accounting, 45(3), 356-374. https://doi.org/10.1016/j.intacc.2010.06.010

Filip, A. \& Raffournier, B. (2010). The value relevance of earnings in a transition economy: the case of Romania. The International Journal of Accounting, 45(1), 77-103. https://doi.org/10.1016/j.intacc.2010.01.004

Goodwin ,J. \& Ahmed, K. (2006). The impact of international financial reporting standards: does size matter? Managerial Auditing Journal, 21(5), 460 - 475. https:// doi.org/10.1108/02686900610067247

Ghosh, T.P. (2017). Significance of IFRS Convergence in India - An Evidence from First-time Adoption of Indian Accounting Standards. Indian Accounting Review, 21(2), 39-59.

Hung, M., Subramanyam, K. R. (2007). Financial statement effects of adopting international accounting standards: the case of Germany. Review of Accounting Studies, 12, 623 -657. https://doi.org/10.1007/s11142-007-9049-9

Haller, A. \& Eierle, B. (2004). The adaptation of German accounting rules to IFRS: A legislative balancing act. Accounting in Europe, 1(1), 27-50. https://doi.org/10.1080/0963818042000262793

Haller, A. \& Wehrfritz, M. (2013). The impact of national GAAP and accounting traditions on IFRS policy selection: Evidence from Germany and the UK. Journal of International Accounting, Auditing and Taxation, 22(1), 39-56. https:// doi.org/10.1016/j.intaccaudtax.2013.02.003

Jermakowicz, E. K., Gornik-Tomaszewski, S. (2006). Implementing IFRS from the perspective of EU publicly traded companies. Journal of International Accounting, Auditing and Taxation, 15, 170 -196. https://doi.org/10.1016/j.intaccaudtax.2006.08.003

Kabir, M.H., Laswad, F. \& Islam, M.A. (2010). Impact of IFRS in New Zealand on accounts and earnings quality, Australian Accounting Review, 20(55), 343-357. https://doi.org/10.1111/j.1835-2561.2010.00106.x

Maria C.H. (2015). Impact of the IFRS Adoption on Financial Assets and Liabilities. Empirical Evidence from Bucharest Stock Exchange. Review of Economic and Business Studies, 8(2), Dec., 69-90. https://doi.org/ 10.1515/rebs-2016-0004

Piotr B. (2014). The impact of IFRS on the value relevance of accounting data of banks listed on the Warsaw stock exchange. Copernican Journal of Finance \& Accounting, 3(1), 34-43. 
Ramona N. (2014). The Effects of IFRS on net income and equity: evidence from Romanian listed companies. Procedia Economics and Finance, 15, 1787 - 1790, Elsevier. https://doi.org/10.1016/S2212-5671(14)00860-0

Stent, W., Bradbury, M. \& Hooks, J. (2010). IFRS in New Zealand: effects on financial statements and ratios. Pacific Accounting Review, 22(2), 92-107. https://doi.org/10.1108/01140581011074494

Terzi, S., Oktem, R. \& Sen, I.K. (2013). Impact of adopting international financial reporting standards: empirical evidence from Turkey. International Business Research, 6(4), 55-66. https://doi.org/10.5539/ibr.v6n4p55

\section{Appendix 1}

Non-parametric test result of Research Hypotheses $1 \& 2$

\begin{tabular}{llll}
\hline Null hypothesis & Test & Sig. & Decision \\
\hline $\begin{array}{l}\text { The median differences between } \\
\text { IGAAP Equity ( 2016) and Ind AS } \\
\text { Equity (2016) equals 0 }\end{array}$ & $\begin{array}{l}\text { Related samples } \\
\text { Wilcoxon Signed } \\
\text { Rank Test }\end{array}$ & .000 & $\begin{array}{l}\text { Reject the null } \\
\text { hypothesis }\end{array}$ \\
$\begin{array}{l}\text { The median differences between } \\
\text { IGAAP Equity ( 2015) and Ind AS } \\
\text { Equity (2015) equals 0 }\end{array}$ & $\begin{array}{l}\text { Related samples } \\
\text { Wilcoxon Signed } \\
\text { Rank Test }\end{array}$ & .000 & $\begin{array}{l}\text { Reject the null } \\
\text { hypothesis }\end{array}$ \\
$\begin{array}{l}\text { The median differences between } \\
\text { IGAAP Profit ( 2016) and Ind AS } \\
\text { Profit (2016) equals 0 }\end{array}$ & $\begin{array}{l}\text { Related samples } \\
\text { Wilcoxon Signed } \\
\text { Rank Test }\end{array}$ & .580 & $\begin{array}{l}\text { Retain the null } \\
\text { hypothesis }\end{array}$ \\
\hline
\end{tabular}

Note : Asymptotic significances are displayed. The significance level in 0.05 .

Appendix II

Major differences of IGAAP and Ind AS

\begin{tabular}{|c|c|c|c|}
\hline Issues & IGAAP & Ind AS & $\begin{array}{l}\text { Major differences of Ind AS as } \\
\text { compared to IGAAP having } \\
\text { impact on financial statement } \\
\text { elements }\end{array}$ \\
\hline $\begin{array}{l}\text { 1. Other comprehensive } \\
\text { income }\end{array}$ & $\begin{array}{l}\text { No corresponding } \\
\text { standard }\end{array}$ & $\begin{array}{l}\text { Ind AS 1 Presentation } \\
\text { of Financial } \\
\text { Statements }\end{array}$ & $\begin{array}{l}\text { Separate and classified } \\
\text { presentation of various items of } \\
\text { other comprehensive income }\end{array}$ \\
\hline 2.Inventories & $\begin{array}{l}\text { AS } 2 \text { Valuation of } \\
\text { Inventories }\end{array}$ & Ind AS 2 Inventories & $\begin{array}{l}\text { Fair valuation of purchases } \\
\text { Write back of inventories which } \\
\text { were earlier written down to net } \\
\text { realizable value }\end{array}$ \\
\hline $\begin{array}{l}\text { 3. Prior period and } \\
\text { exceptional items }\end{array}$ & $\begin{array}{l}\text { AS } 5 \text { Net Profit or Loss } \\
\text { for the Period, Prior } \\
\text { Period Items and } \\
\text { Changes in Accounting } \\
\text { Policies }\end{array}$ & $\begin{array}{l}\text { Ind AS } 8 \text { Accounting } \\
\text { Policies, Changes in } \\
\text { Accounting Estimates } \\
\text { and Errors }\end{array}$ & $\begin{array}{l}\text { Methods of correction of prior } \\
\text { period errors } \\
\text { Recognition of exceptional items } \\
\text { as ordinary accounting elements }\end{array}$ \\
\hline 4. Proposed dividend & $\begin{array}{l}\text { AS } 4 \text { Contingencies and } \\
\text { Events Occurring after } \\
\text { the Balance Sheet Date }\end{array}$ & $\begin{array}{l}\text { Ind AS } 10 \text { Events after } \\
\text { the Reporting Period }\end{array}$ & $\begin{array}{l}\text { Non-provisioning of proposed } \\
\text { dividend and related dividend } \\
\text { distribution tax }\end{array}$ \\
\hline 5. Deferred tax & $\begin{array}{l}\text { AS } 22 \text { Accounting for } \\
\text { Taxes on Income }\end{array}$ & $\begin{array}{l}\text { Ind AS } 12 \text { Income } \\
\text { Taxes }\end{array}$ & $\begin{array}{l}\text { Deferred tax measurement on } \\
\text { assets and liabilities carried at fair } \\
\text { value }\end{array}$ \\
\hline
\end{tabular}


6. Componentization of property, plant and equipment

7. Lease accounting

8. Fair valuation of revenue

\section{Segregation of employee benefits \\ 10. Implicit government grant}

\section{Translation of foreign operations}

12. Application of all -in-cost approach

\section{Change in} consolidation method in relation to joint ventures
AS 10 Accounting for Fixed Assets

Ind AS 16 Property, Plant and Equipment

AS 19 Leases

AS 9 Revenue

Recognition

AS 15 Employee

Benefits

AS 12 Accounting for Government Grants

AS 11 The Effects of Changes in

Foreign Exchange Rates

AS 16 Borrowing costs

AS 23 Accounting for Investments in

Associates in

Consolidated

Financial Statements

AS 27 Financial

Reporting of Interests in Joint Ventures
AS 17 Leases

Ind AS 18 Revenue

Ind AS 19 Employee

Benefits

Ind AS 20 Accounting for Government Grants and Disclosure of Government

Assistance

Ind AS 21 The Effects of Changes in Foreign Exchange Rates

Ind AS 23 Borrowing Costs

Ind AS 28 Investments in Associates and Joint Ventures
Depreciation impact arising out of componentization of property, plant and equipment

Impact on repairs and maintenance and depreciation arising out of capitalization of major spares

Reclassification of leasehold land as operating lease

Allocation of operating lease rental

Recognition of an arrangement as lease

Fair valuation of deferred revenue

Deferral revenue based on continuing involvement in goods sold

Fair valuation of service concession arrangements

Provisioning for customer loyalty programs

Segregation of OCI and expense elements out of post-employment benefits

Fair valuation of government grant out of interest-free or concessional government loan

Translation of integral and non-integral foreign operations applying current rate method

Recognition of borrowing cost on financial liabilities measured at amortized cost applying implicit interest rate

Application of equity method accounting joint ventures 


\begin{tabular}{|c|c|c|c|}
\hline $\begin{array}{l}\text { 14. Distinguishing } \\
\text { equity and financial } \\
\text { liability }\end{array}$ & $\begin{array}{l}\text { No corresponding } \\
\text { standard }\end{array}$ & $\begin{array}{l}\text { Ind AS } 32 \text { Financial } \\
\text { Instruments : } \\
\text { Presentation }\end{array}$ & $\begin{array}{l}\text { Accounting for preference shares } \\
\text { Accounting for convertibles }\end{array}$ \\
\hline 15. Impairment analysis & $\begin{array}{l}\text { AS } 28 \text { Impairment of } \\
\text { Assets }\end{array}$ & $\begin{array}{l}\text { Ind AS } 36 \text { Impairment } \\
\text { of Assets }\end{array}$ & $\begin{array}{l}\text { Change in method of measuring } \\
\text { value in use - replacement of net } \\
\text { realizable value by fair value less } \\
\text { costs to sale }\end{array}$ \\
\hline \multirow{2}{*}{$\begin{array}{l}\text { 16. Discounting of } \\
\text { provisions }\end{array}$} & \multirow{2}{*}{$\begin{array}{l}\text { AS } 29 \text { Provisions, } \\
\text { Contingent Liabilities } \\
\text { and Contingent Assets }\end{array}$} & \multirow{2}{*}{$\begin{array}{l}\text { Ind AS } 37 \text { Provisions, } \\
\text { Contingent Liabilities } \\
\text { and Contingent Assets }\end{array}$} & Discounting of provisions \\
\hline & & & $\begin{array}{l}\text { Recognition of decommissioning } \\
\text { provisions }\end{array}$ \\
\hline 17. Biological assets & $\begin{array}{l}\text { No corresponding } \\
\text { standard }\end{array}$ & Ind AS 41 Agriculture & $\begin{array}{l}\text { Measurement of biological assets } \\
\text { at fair value }\end{array}$ \\
\hline \multirow[t]{2}{*}{ 18. Fair valuation } & \multirow[t]{2}{*}{ Guidance Note } & \multirow[t]{2}{*}{$\begin{array}{l}\text { Ind AS } 102 \\
\text { Share-based Payment }\end{array}$} & $\begin{array}{l}\text { Fair valuation of employee stock } \\
\text { option }\end{array}$ \\
\hline & & & $\begin{array}{l}\text { Fair valuation of tangible and } \\
\text { intangible assets purchased } \\
\text { under share based payment }\end{array}$ \\
\hline $\begin{array}{l}\text { 19. Switching over to } \\
\text { purchase accounting }\end{array}$ & $\begin{array}{l}\text { AS } 14 \text { Accounting for } \\
\text { Amalgamations }\end{array}$ & $\begin{array}{l}\text { Ind AS } 103 \text { Business } \\
\text { Combinations }\end{array}$ & $\begin{array}{l}\text { Fair valuation of assets and } \\
\text { liabilities acquired and purchase } \\
\text { consideration }\end{array}$ \\
\hline $\begin{array}{l}\text { 20. Change in } \\
\text { measurement principle }\end{array}$ & $\begin{array}{l}\text { AS } 10 \text { Accounting for } \\
\text { Fixed Assets }\end{array}$ & $\begin{array}{l}\text { Ind AS } 105 \\
\text { Non-current Assets } \\
\text { Held for Sale and } \\
\text { Discontinued } \\
\text { Operations }\end{array}$ & $\begin{array}{l}\text { Application of lower of cost and } \\
\text { fair value less costs to sale } \\
\text { approach }\end{array}$ \\
\hline \multirow[t]{5}{*}{$\begin{array}{l}\text { 21. Fair valuation and } \\
\text { impairment }\end{array}$} & \multirow{5}{*}{$\begin{array}{l}\text { Partly covered by } \\
\text { AS } 13 \text { Accounting for } \\
\text { Investments }\end{array}$} & \multirow[t]{5}{*}{$\begin{array}{l}\text { Ind AS } 109 \text { Financial } \\
\text { Instruments }\end{array}$} & $\begin{array}{l}\text { Fair valuation of financial assets } \\
\text { and financial liabilities }\end{array}$ \\
\hline & & & Impairment analysis \\
\hline & & & $\begin{array}{l}\text { Fair value accounting for } \\
\text { derivatives }\end{array}$ \\
\hline & & & Hedge accounting \\
\hline & & & $\begin{array}{l}\text { Change in valuation of long term } \\
\text { receivables and payables }\end{array}$ \\
\hline \multirow[t]{2}{*}{$\begin{array}{l}\text { 22. Ind AS impact on } \\
\text { financial statements of } \\
\text { subsidiary }\end{array}$} & \multirow[t]{2}{*}{$\begin{array}{l}\text { AS } 21 \text { Consolidated } \\
\text { financial statements }\end{array}$} & \multirow[t]{2}{*}{$\begin{array}{l}\text { Ind AS } 110 \\
\text { Consolidated Financial } \\
\text { Statements }\end{array}$} & $\begin{array}{l}\text { Change in valuation of assets and } \\
\text { liabilities of subsidiary companies } \\
\text { arising out of Ind AS application }\end{array}$ \\
\hline & & & Impact on minority interest \\
\hline
\end{tabular}

